\title{
TIR2 and TIR4 are involved in the treatment of rheumatoid arthritis synovial fibroblasts with a medicated serum of asarinin through inhibition of $T_{h} 1 / T_{h} 17$ cytokines
}

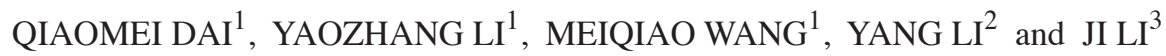 \\ ${ }^{1}$ Department of Pathology, Heilongjiang University of Chinese Medicine, Xiangfang, Harbin 150040; \\ ${ }^{2}$ Department of Rheumatology and Immunology, The Second Affiliated Hospital of Harbin Medical University, Harbin 150081; \\ ${ }^{3}$ Department of Chinese Formulae, Heilongjiang University of Chinese Medicine, Xiangfang, Harbin 150040, P.R. China
}

Received May 4, 2019; Accepted January 31, 2020

DOI: $10.3892 /$ etm.2020.8557

\begin{abstract}
Asarinin is one of the main active chemical components isolated from Xixin, a Chinese medicine. To investigate the role of asarinin in rheumatoid arthritis (RA), the present study investigated the effect of an asarinin-medicated serum on human fibroblast-like synoviocytes in vitro. An asarinin-medicated serum was generated and analyzed by high-performance liquid chromatography. Fibroblast-like synoviocytes were isolated from patients with osteoarthritis and RA. The third generation of the rheumatoid synoviocytes was used in the experimental research and the third generation of osteoarthritic synoviocytes was used as control cells. Trypan blue staining was performed to detect the viability of RA synovial fibroblasts (RASFs). ELISA, reverse transcription-quantitative (RT-q) PCR and western blotting were also performed to detect the expression of various cytokines. Additionally, RT-qPCR was employed to detect Toll-like receptor (TLR) 2 and TLR4. The results revealed that medicated asarinin serum inhibited the viability of RASFs in a dose- and time-dependent manner. The serum also suppressed the expression of interleukin (IL)-17A, tumor necrosis factor- $\alpha$, interferon- $\gamma$, IL-6, TLR2 and TLR4. The inhibitory effect of asarinin drug serum on RASFs may be achieved by inhibition of $T$ helper cell $\left(T_{h}\right) 1 / T_{h} 17$ cytokines through suppression of TLR2 and TLR4.
\end{abstract}

\section{Introduction}

Rheumatoid arthritis (RA) is an autoimmune disease that is mainly mediated by cytokines and is characterized by the abnormal proliferation of synovial cells, the massive infiltration

Correspondence to: Professor $\mathrm{Ji} \mathrm{Li}$, Department of Chinese Formulae, Heilongjiang University of Chinese Medicine, 24 Heping Road, Xiangfang, Harbin 150040, P.R. China

E-mail: 3078763598@qq.com

Key words: asarinin, medicated serum, rheumatoid arthritis synovial fibroblasts, T helper cell 1, T helper cell 17, toll-like receptor of inflammatory cells and the progressive destruction of joints (1). $T$ helper cells $\left(T_{h}\right)$ are divided into $T_{h} 1, T_{h} 2$ and $T_{h} 17$ subgroups according to the different expression profiles of secretory cytokines (2). It has become clear in the last few years that T cell-derived cytokines expressed preferentially by $\mathrm{T}_{\mathrm{h}} 1$ cells contribute to joint destruction and inflammatory response in RA, whereas $\mathrm{T}_{\mathrm{h}} 2$ cell-associated cytokines may be protective $(2,3)$. However, recent research on $T_{h} 17$ cells and regulatory $T$ cells (Treg) has demonstrated that an imbalance between $T_{h} 1 / T_{h} 2 / T_{h} 17 /$ Treg cells is important to the pathogenesis of RA (4-6). Although the origin of RA is unclear, it has been determined that lymphocytes accumulate around the terminal blood vessels of the subsynovial layer prior to the inflammatory response (7). The synovium is composed of two layers, namely the synovial lining layer (lining cells) and the lower synovial lining layer (or supporting layer) (8). Another major feature of RA is the abnormal proliferation of synovial cells in the lining layer and the expression of transformed cells, which erode the surrounding bone and cartilage (7-9). Increasing evidence has confirmed that the activation state of RA synovial fibroblasts (RASFs) is critically dependent on TLR expression, which in turn is known to serve an essential role in $\mathrm{T}$ cell differentiation and function (10-12). TLR2 and TLR4 have been revealed to serve important functions in pathogenesis of RA and they has been determined that the expression of TLR-2 and TLR-4 is increased and regulated by proinflammatory cytokines that are present in the synovial compartment (10). Activation of these RASF-expressed TLRs exacerbates inflammatory $T_{h} 1$ and $\mathrm{T}_{\mathrm{h}} 17$ cell expansion in cell-cell contact-dependent and inflammatory cytokine-dependent pathways, inducing the increased accumulation of interferon (IFN)- $\gamma$ and interleukin (IL)-17 (11). Targeting TLRs may therefore modulate inflammation in RA and provide novel therapeutic strategies for overcoming this persistent disease (12).

Xixin is isolated from the dried roots and rhizomes of Asarum heterotropoides f. mandshuricum (Maximowicz) Kitagawa, A. sieboldii Miq. var. seoulense Nakai and A. sieboldii Miq. (Aristolochiaceae), and is a commonly used herbal medicine in China (13). Xixin is used to treat colds, fever, chills, headaches, acute toothaches, sinusitis, coughs and RA in traditional Chinese medicine (13). Asarinin (molecular weight, 354.35) is one of the main active chemical components 
isolated from Xixin (13-16). Many pharmacological effects have been identified in asarinin, including anti-inflammatory effects, antipyretic properties and immune inhibition (13-16).

A previous study indicated that asarinin significantly inhibited the macroscopic score and cartilage destruction of collagen-induced arthritis (17). However, little is known about the effect of asarinin on RA synovial fibroblasts. The present study aimed to determine the pharmacological profile of asarinin and its potential effect on RA (18).

The present study used RA synovial fibroblasts to examine the effect of asarinin and the possible roles of $T_{h} 17, T_{h} 1$ and TLRs in the pathogenesis of arthritis.

\section{Materials and methods}

Reagents. Recombinant Human tumor necrosis factor (TNF)- $\alpha$ and IL-1 $\beta$ were obtained from PeproTech China. Fetal bovine serum and high-glucose DMEM were purchased from HyClone; GE Healthcare Life Sciences. Trypsin-EDTA solution and the Trypan Blue Staining Cell Viability Assay kit were purchased from Beyotime Institute of Biotechnology. The RNA PCR kit (EX TAQ R-PCR Version 2.1) was obtained from Takara Biotechnology Co., Ltd., and primers and probes were purchased from Sangon Biotech Co., Ltd. TRIzol ${ }^{\circledR}$ reagent was purchased from Invitrogen. Asarinin was purchased from Chengdu Must Bio-Technology Co., Ltd., and ELISA kits for TNF- $\alpha$ (cat. no. 555212), IL-6 (cat. no. 555220) and IFN- $\gamma$ (cat. no. 555142) from BD Biosciences. The ELISA kit for IL-17A (cat. no. D1700) was obtained from R\&D Systems, Inc. Primary antibodies for TNF- $\alpha$ (cat. no. TA808184), IL-17A (cat. no. TA337063), IL-6 (cat. no. TA500067) and IFN- $\gamma$ (cat. no. TA353236) were from OriGene Technologies, Inc. Peptidoglycan (PGN) and lipopolysaccharide (LPS) were purchased from Sigma-Aldrich.

Preparation of the asarinin-medicated serum. Asarinin and olive oil were mixed in a ratio of 5:1 to form a suspension for the asarinin-medicated serum. The asarinin-medicated serum was generated according to previous studies $(19,20)$. A total of 20 female Sprague-Dawley (age range, 6-8 weeks; weight 200-250 g) were supplied by the Experimental Animals Department of the Second Affiliated Hospital of Harbin Medical University. Animals were housed in an airconditioned room (temperature, $22 \pm 2^{\circ} \mathrm{C}$; humidity, $55 \pm 5 \%$ ) with a $12 \mathrm{~h}$ light-dark cycle and free access to a standard diet with free access to tap water. Sprague-Dawley (SD) rats were randomly divided into an asarinin group and a blank serum group. Asarinin $(30 \mathrm{mg} / \mathrm{kg})$ was administered orally to SD rats twice daily for 5 days. Rats in the blank serum group received saline twice daily for 5 days. The same dose was administered orally to the blank serum group and the asarinin group. Then, $1 \mathrm{~h}$ after the last administration, rats were anesthetized via intraperitoneal injection of pentobarbital and blood samples $(10 \mathrm{ml})$ were collected from the abdominal aorta for subsequent experiments. The Ethics Committee for Experimental Animals of Harbin Medical University reviewed and approved the current study and all animals were treated according to the guidelines of the animal ethics committee.

Rat plasma sample preparation for high-performance liquid chromatography (HPLC) analysis. Rat medicated sera and blank sera were subjected to HPLC analysis using a Thermo Fisher Ultimate 3000 UHPL (Thermo Fisher Scientific, Inc.) $(21,22)$. Chromatographic conditions: The C18 column used was supplied by Thermo Fisher Scientific, Inc. $(4.6 \times 150 \mathrm{~mm} ; 5 \mu \mathrm{m})$. The mobile phase consisted of acetonitrile-water (50:50) and the running time was $32 \mathrm{~min}$. Additionally, the column temperature was $30^{\circ} \mathrm{C}$ and the flow rate $1 \mathrm{ml} / \mathrm{min}$. The detection wavelengths were set at 287 $\mathrm{nm}$ with a sample size of $10 \mu \mathrm{l}$. Asarinin serum $(1 \mathrm{ml})$ was obtained and dissolved by ultrasonography with methanol added to a final volume of $5 \mathrm{ml}$. Sera were filtered through 0.45 microporous membranes for analysis.

Patients, tissue specimens and ethics statement. Synovial tissue specimens used for the culture of OA synovial fibroblasts (OASFs; $n=3$ ) and RASFs $(n=4)$ were obtained from the knees of patients following joint replacement surgery, which was a procedure performed in patients who had severe, long-term disease and who had received numerous therapies over many years. All patients fulfilled the American College of Rheumatology 2010 criteria for RA and the 1995 criteria for osteoarthritis (OA) and provided their written consent to participate in the current study $(23,24)$. Synovial tissue specimens from 4 patients with RA [ 2 females (mean age, $67.9 \pm 4.8$ years) and 2 males (age, $70.1 \pm 3.5$ years)] and 3 patients with OA [3 females (age, 68.2 \pm 5.3 years)]. Patients were recruited from September 2017 to September 2018.The study protocols, consent forms and consent procedure were approved by the Institutional Medical Ethics Review Board of the Second Affiliated Hospital of Harbin Medical University.

Synovial fibroblast $(S F)$ isolation, culture and treatment. Human SFs were isolated from synovial tissue obtained at the time of knee replacement surgery from 4 patients with RA and 3 patients with OA. Synoviocytes were trypsinized and suspended in DMEM containing 10-20\% fetal bovine serum, inoculated in a culture flask and cultured in a cell incubator at $37^{\circ} \mathrm{C}$ and $5 \% \mathrm{CO}_{2}$. The following day, the medium was changed, and the unattached cells were discarded. The cells that remained adherent were considered to be synovial cells. The medium was subsequently changed once every 3-4 days and the culture solution was discarded once the synovial cells reached $80-90 \%$ confluence in the flask. Cells were then rinsed twice with PBS. Digestion was terminated when the majority of cells changed shape from diamond to round and were bright in appearance. Cells were generally passaged at a ratio of $1: 2$ or 1:3. After 3 generations, it was revealed that 95\% of cells were fibroid synovial cells, which were used in the present study. OASFs and RASFs were pretreated with IL-1 $\beta(2 \mathrm{ng} / \mathrm{ml})$ and TNF- $\alpha(10 \mathrm{ng} / \mathrm{ml})$. OASFs $\left(5 \times 10^{6}\right.$ cells $)$ and RASFs $\left(5 \times 10^{6}\right.$ cells) per well were stimulated with medicated serum of asarinin, toll-like receptor (TLR)2 ligand PGN $(10 \mathrm{ng} / \mathrm{ml})$ and TLR4 ligand LPS (100 ng/ml).

Cell viability determination. OASFs $\left(5 \times 10^{6}\right.$ cells) and RASFs $\left(5 \times 10^{6}\right.$ cells) were seeded into 96-well plates and treated with medicated serum of asarinin at a series of concentrations $(5,10$, $15,20,25$ or $30 \%)$ for $6 \mathrm{~h}$ or medicated serum of asarinin (15\%) for $6,12,18$ or $24 \mathrm{~h}$. Asarinin at a dosage of $15 \%$ was selected as cell death did not affect subsequent experiments. Cell suspensions 
in PBS $(10 \mu \mathrm{l})$ were mixed with trypan blue $(40 \mu \mathrm{l})$ for $5 \mathrm{~min}$ at room temperature and the number of stained (dead) and unstained (alive) cells were counted using a hemocytometer $(25,26)$.

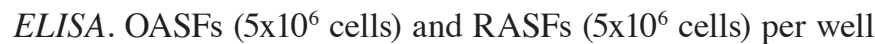
were stimulated with medicated serum of asarinin (15\%) for $6 \mathrm{~h}$, after which the culture supernatants were collected and stored at $-20^{\circ} \mathrm{C}$ for subsequent ELISA. Levels of TNF- $\alpha$, IFN- $\gamma$, IL-17A and IL- 6 in cell culture supernatants were measured using ELISA kits, in accordance with the manufacturer's protocol.

$R N A$ preparation and reverse transcription-quantitative

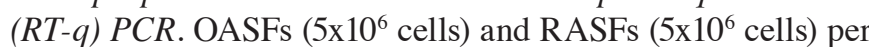
well were stimulated with medicated serum of asarinin $(15 \%)$ for $6 \mathrm{~h}$ and the cells were harvested and stored at $-80^{\circ} \mathrm{C}$ until analysis. Total mRNA was isolated from synovial fibroblasts using TRIzol ${ }^{\circledR}$ and cDNA was synthesized from $1 \mu \mathrm{g}$ total RNA using oligo-dT primers and AMV reverse transcriptase according to the manufacturer's protocol. The conditions of reverse transcription were as follows: $30^{\circ} \mathrm{C}$ for $10 \mathrm{~min}$, $42^{\circ} \mathrm{C}$ for $30 \mathrm{~min}, 99^{\circ} \mathrm{C}$ for $5 \mathrm{~min}$ and $5^{\circ} \mathrm{C}$ for $5 \mathrm{~min}$. Samples were stored at $-20^{\circ} \mathrm{C}$ until further use. The following primer sequences were used for RT-qPCR. $\beta$-actin forward, 5 '-AGC GGTTCCGATGCCCT-3' and reverse, 5'-AGAGGTCTTTAC GGATGTCAACG-3'; IFN- $\gamma$ forward, 5'-TGAACGCTACAC ACTGCATCTTGG and reverse, 5'-CGACTCCTTTTCCGC TTCCTG G-3'; IL-17A forward, 5'-AGTGAAGGCAGCAGC GATCAT-3' and reverse, 5'-CGCCAAGGGAGTTAAAG-3'; TNF- $\alpha$ forward, 5'-TCTCATCAGTTCTATGGCCC-3' and reverse, 5'-GGGAGTAGACAAGGTACAAC-3'; IL-6 forward, 5'-TCCAGTTGCCTTCTTGGGAC-3' and reverse, 5'-GTG TAATTAAGCCTCCGACTTG-3'; TLR2 forward, 5'-ACC AAGTGAAGGTACCTGTGGGGC-3' and reverse, 5'-GCA CCAGAGCCTGGAGGTTCAC-3'; TLR4 forward, 5'-CCC CGACAACCTCCCCTTCTCA-3' and reverse, 5'-TCCAGA AAAGGCTCCCAGGGCT-3'.

RT-qPCR was performed at a final concentration of $0.15 \mu \mathrm{l}$ primer and $0.25 \mu \mathrm{l}$ of Ex Taq HS polymerase (Takara Biotechnology Co., Ltd.) in standard PCR buffer. Transcripts were quantified using EX TAQ R-PCR. PCR was performed with a reaction mix comprising $0.5 \mu \mathrm{l}$ forward and reverse primers, $2 \mu \mathrm{l}$ cDNA and $1 \mu \mathrm{l}$ TaqMan probe template to a total volume of $25 \mu \mathrm{l}$. PCR was initiated for $2 \mathrm{~min}$ at $95^{\circ} \mathrm{C}$, continued with 40 cycles of $10 \mathrm{sec}$ at $95^{\circ} \mathrm{C}, 40 \mathrm{sec}$ at $60^{\circ} \mathrm{C}$ and final extension for $5 \mathrm{~min}$ at $72^{\circ} \mathrm{C}$. The fold changes in the expression of each gene were calculated using the $2^{-\Delta \Delta} \mathrm{Cq}$ method (27), with the housekeeping gene $\beta$-actin mRNA as an internal control.

Western blot analysis. RASFs $\left(5 \times 10^{6}\right.$ cells $)$ and OASFs $\left(5 \times 10^{6}\right.$ cells) were pretreated with IL- $1 \beta(2 \mathrm{ng} / \mathrm{ml})$ and TNF- $\alpha$ $(10 \mathrm{ng} / \mathrm{ml})$, and incubated with medicated serum of asarinin at $37^{\circ} \mathrm{C}$ for $6 \mathrm{~h}$. The cells were harvested and stored at $-80^{\circ} \mathrm{C}$ until analysis. Ice-cold lysis buffer $(40 \mathrm{ml})$ was used to lyse cells. Protein concentration was measured using the BCA method. Samples $(10 \mu \mathrm{l})$ were separated using SDS-PAGE in a $10 \%$ polyacrylamide gel and transferred electronically to a PVDF membranes. The membranes were then blocked with Tris-buffered saline containing $0.1 \%$ Tween-20 and 5\% nonfat milk at $37^{\circ} \mathrm{C}$ for $1 \mathrm{~h}$. Samples were then incubated with the following primary antibodies at $4^{\circ} \mathrm{C}$ overnight: IFN- $\gamma$, IL-6,
TNF- $\alpha$ and IL-17A (1:500). After three washes with PBST (0.5\% Tween 20 in PBS), membranes were incubated with horseradish peroxidase-conjugated IgG (cat. no. PV6002; OriGene Technologies, Inc.) secondary antibodies for $1 \mathrm{~h}$ at $37^{\circ} \mathrm{C}$. Samples were visualized via chemiluminescence using an ECL Plus Detection kit (Beyotime Institute of Biotechnology). The protein expression levels were then determined by analyzing the signals captured on the PVDF membranes using a ChampGel 5500 (Beijing Sage Creation Science Co, Ltd.).

Statistical analysis. Samples were run in triplicate and the data were presented as the mean \pm standard deviation. Statistically significant differences were analyzed via one-way analysis of variance followed by and SNK test using SPSS software 13.0 for Windows (SPSS, Inc.). $\mathrm{P}<0.05$ was considered to indicate a statistically significant difference.

\section{Results}

HPLC of medicated serum of asarinin. The chemical structures of asarinin are provided in Fig. 1A. No peak for asarinin was detected in the blank serum group (Fig. 1B) but was present for the control asarinin (Fig. 1C) and in rat medicated serum (Fig. 1D). The extra peak ( 26.635 min) may represent a secondary metabolite of asarinin (Fig. 1D).

Medicated serum of asarinin inhibits human RASF proliferation. To examine the effect of medicated serum of asarinin on the proliferation of RASFs, trypan blue staining was performed to detect the viability of RASFs. The results demonstrated that medicated serum of asarinin decreased the viability of RASFs and OASFs in a dose- and time-dependent manner (Fig. 2A-C). A significant decrease was observed in the cell number of RASFs compared with that of OASFs (Fig. 2D).

Regulation of inflammatory cytokines on rheumatoid synoviocytes by medicated serum of asarinin. RA and OA samples were collected from the discarded tissue of patients following knee joint replacement surgery. Third generation rheumatoid synoviocytes and osteoarthritic synoviocytes were used in the current study. The results revealed that third generation rheumatoid synoviocytes and osteoarthritic synoviocytes exhibited fibroblast-like synovial cell morphology (Fig. 3A). TNF- $\alpha$, IFN- $\gamma$, IL- 6 and IL-17A are important inflammatory mediators in RA (2). RT-qPCR analysis for IL-17A, TNF- $\alpha$, IFN- $\gamma$ and IL-6 expression revealed a decrease following asarinin treatment compared with control and treated cells (Fig. 3B). Western blot analyses for TNF- $\alpha$, IFN- $\gamma$, IL- 6 and IL-17A expression also revealed a decrease compared with the controls (Fig. 3C). The effect of asarinin on IL-17A, TNF- $\alpha$, IFN- $\gamma$ and IL-6 in RASFs was also measured by ELISA, revealing similar results (Fig. 3D).

Inhibition of TLR2 and TLR4 on rheumatoid synoviocytes by medicated serum of asarinin. RT-qPCR analysis for TLR2 and TLR4 expression revealed a decrease following asarinin treatment (Fig. 4).

\section{Discussion}

Xixin is a commonly used herbal medicine in China and other Asian countries. Asarinin is one of the main active chemical 
A

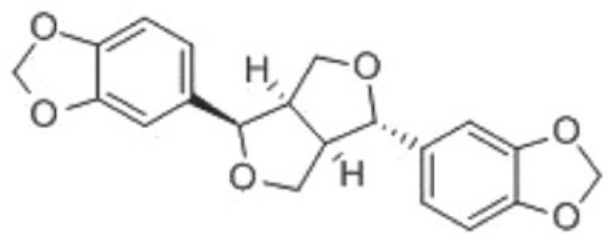

B
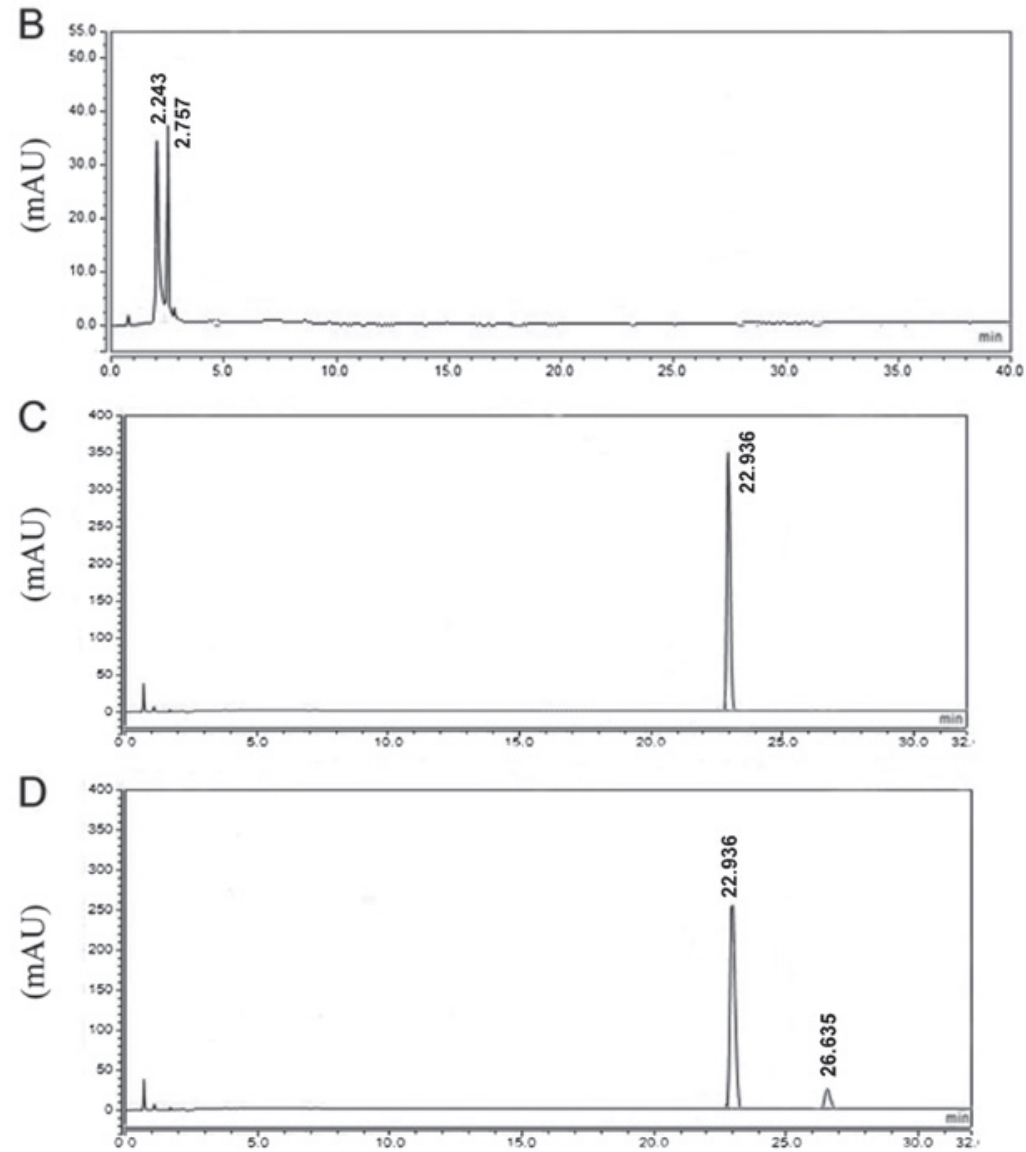

Figure 1. HPLC profiles of rat medicated sera after the oral administration of asarinin. (A) The chemical structure of asarinin. (B) Blank serum, (C) control asarinin and (D) rat medicated serum of asarinin HPLC profiles are presented. A distinct peak was detected in rat medicated serum and the asarinin control, but not in blank serum. HPLC, high-performance liquid chromatography.

components isolated from Xixin (13). Despite a previous study revealing that asarinin significantly inhibited the macroscopic score and cartilage destruction of collagen-induced arthritis (17), little is known about the effect of asarinin on RA synovial fibroblasts. The present study therefore aimed to assess the effects of asarinin on RASFs.

$\mathrm{RA}$ is an autoimmune disease characterized by chronic inflammation that leads to joint destruction (28). Although the pathogenesis of RA, mediated by T cells, is not completely clear, certain $\mathrm{T}_{\mathrm{h}}$ 1-type cytokines, including IFN- $\gamma$, TNF- $\alpha$ and IL-1, $\mathrm{T}_{\mathrm{h}}$ 2-type cytokines, including IL-4 and IL-10, $\mathrm{T}_{\mathrm{h}} 17$ cytokines, including IL-17 and IL-22, and Treg cells interact to activate synovial macrophages, fibroblasts and osteoclasts to affect chronic inflammation and joint destruction (29-32). RASFs are leading cells in joint erosion and contribute actively to inflammation.

Synovial cells are the most important cells in the synovial layer. The primary target of RA immune activity is located in the synovium. There are two types of cells in the synovial layer: Type A (macrophage-like synovial cells) and type B (fibroblast-like synoviocytes; FLSs) (33). Synovial cells, particularly FLSs of the synovial layer, participate in the function of motor joints, producing joint lubrication fluids and maintaining the compliance and integrity of the synovial fluid, cartilage nutrition and the synovial layer $(33,34)$. Rheumatoid arthritis synovial fibroblasts are leading cells in joint erosion and contribute actively to inflammation, and enhance cell proliferation and invasiveness under the action of various cytokines and growth factors (28). During the disease progression of RA, the fibroid synovial cells function as passive responders and active invaders after transformation (35). Therefore, the present study used third generation rheumatoid synoviocytes and osteoarthritic synoviocytes. Since certain compounds of asarinin may change at room temperature after being dissolved in solvents, the current study used medicated serum of asarinin on cells. The results demonstrated that medicated serum of asarinin decreased the viability of RASFs and OASFs in a time-dependent manner within $24 \mathrm{~h}$. Furthermore, when the concentration and duration of drug-containing serum were significantly 

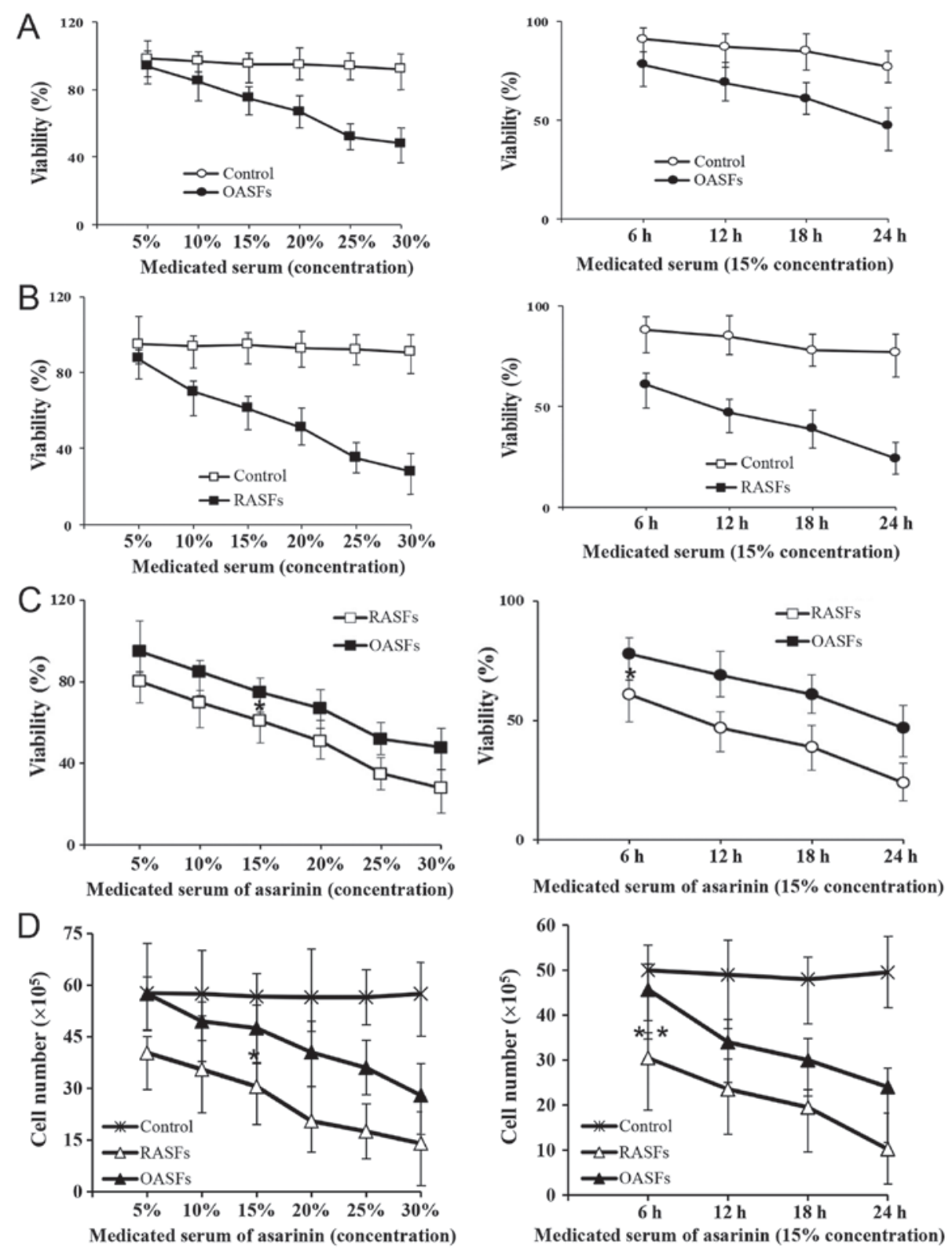

Figure 2. Effect of asarinin at different concentrations on the proliferation of human SFs after treatment for different times. (A) Left: Viability of OASFs in different concentrations of medicated serum of asarinin. Right: Viability of OASFs at different times after medicated serum of asarinin treatment. (B) Left: Viability of RASFs in different concentrations of medicated serum of asarinin. Right: Viability of human RASFs at different times after medicated serum of asarinin treatment. (C) Left: Viability of human SFs in different concentrations of medicated serum of asarinin. Right: Viability of human SFs at different times after medicated serum of asarinin treatment. (D) Left: Cell number in different concentrations of medicated serum of asarinin. Right: Cell numbers at different times after medicated serum of asarinin treatment. ${ }^{*} \mathrm{P}<0.05$ and ${ }^{* *} \mathrm{P}<0.01$ vs. control cells. SF, synovial fibroblast; OASF, osteoarthritis SF; RASF, rheumatoid arthritis SF; Control, blank serum.

increased, the number of RASFs was significantly reduced and the number of OASFs was correspondingly reduced. However, the reduction of the latter was less compared with that of the former. When OASFs and RASFs were treated with blank serum, no significant decrease in cell viability was observed. FLSs of RA exhibit tumor-like growth characteristics, and the excessive abnormal proliferation and apoptosis of these cells serve an important role in synovial inflammation and bone destruction in RA (36). The effect of asarinin on FLS may be associated with the immunosuppressive effect of asarinin. However, whether the medicated serum of asarinin causes RASF necrosis or apoptosis requires elucidation.
To clarify the mechanism of action of asarinin on RA, OASFs were used as control cells to detect the cytokines associated with RA pathogenesis. The results demonstrated that asarinin downregulated the expression of TNF- $\alpha$, IFN- $\gamma$, IL-6 and IL-17A in RA synovial cells. The expression of $\mathrm{T}_{\mathrm{h}} 2$ cytokines (IL-4 and IL-5) were too low to be detected (data not shown). TNF- $\alpha$, IFN- $\gamma$, IL-6 and IL-17A were also expressed in OA synovial cells, but TNF- $\alpha$, IFN- $\gamma$, IL- 6 and IL-17A expression was low and no significant differences were observed before and after asarinin treatment. IFN- $\gamma$, IL- 6 , TNF- $\alpha$ and IL-17A are inflammatory cytokines and IFN- $\gamma$ and TNF- $\alpha$ are $\mathrm{T}_{\mathrm{h}}$ 1-type cytokines (6). IL-6 is also the main inflammatory factor in RA joint inflammation, but its pathogenic effect is 


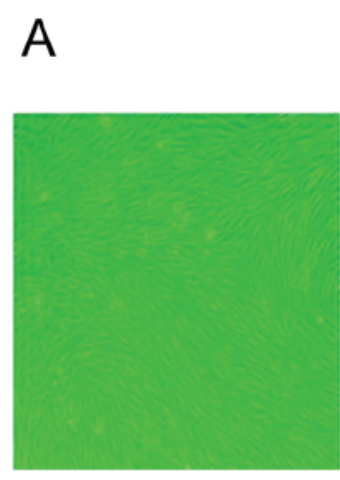

$(\operatorname{RASF} 40 \times)$

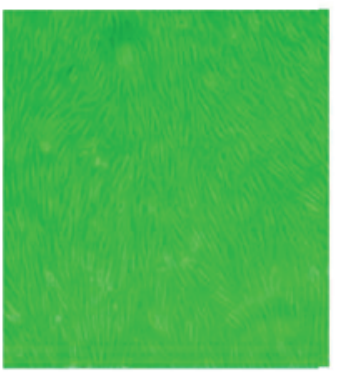

$($ OASF $40 \times)$

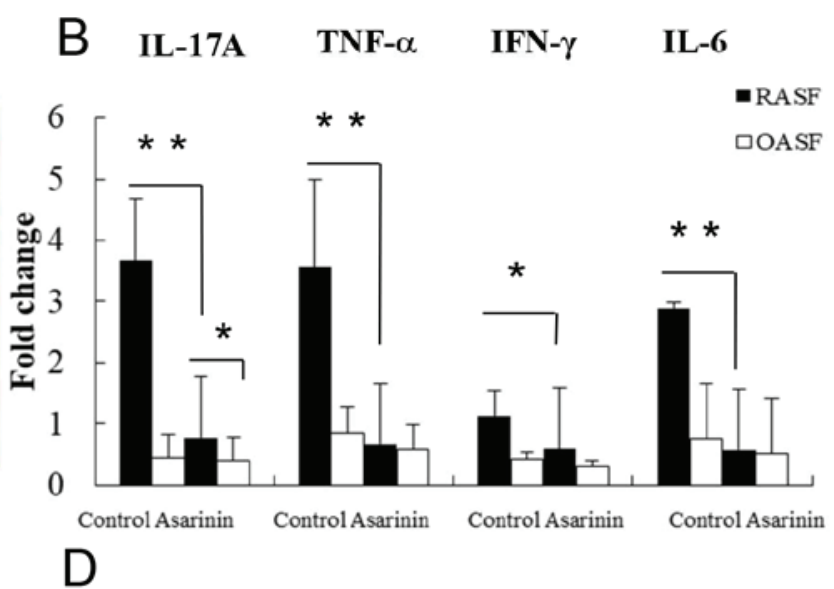

C

RA OA RA OA

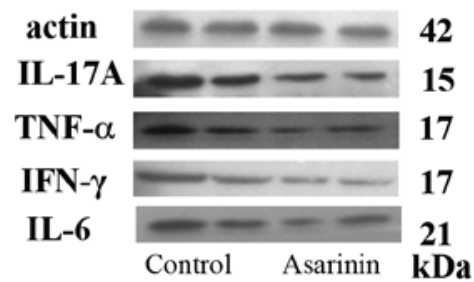

\section{IL-17A TNF- $\alpha \quad$ IFN- $\gamma \quad$ IL-6}
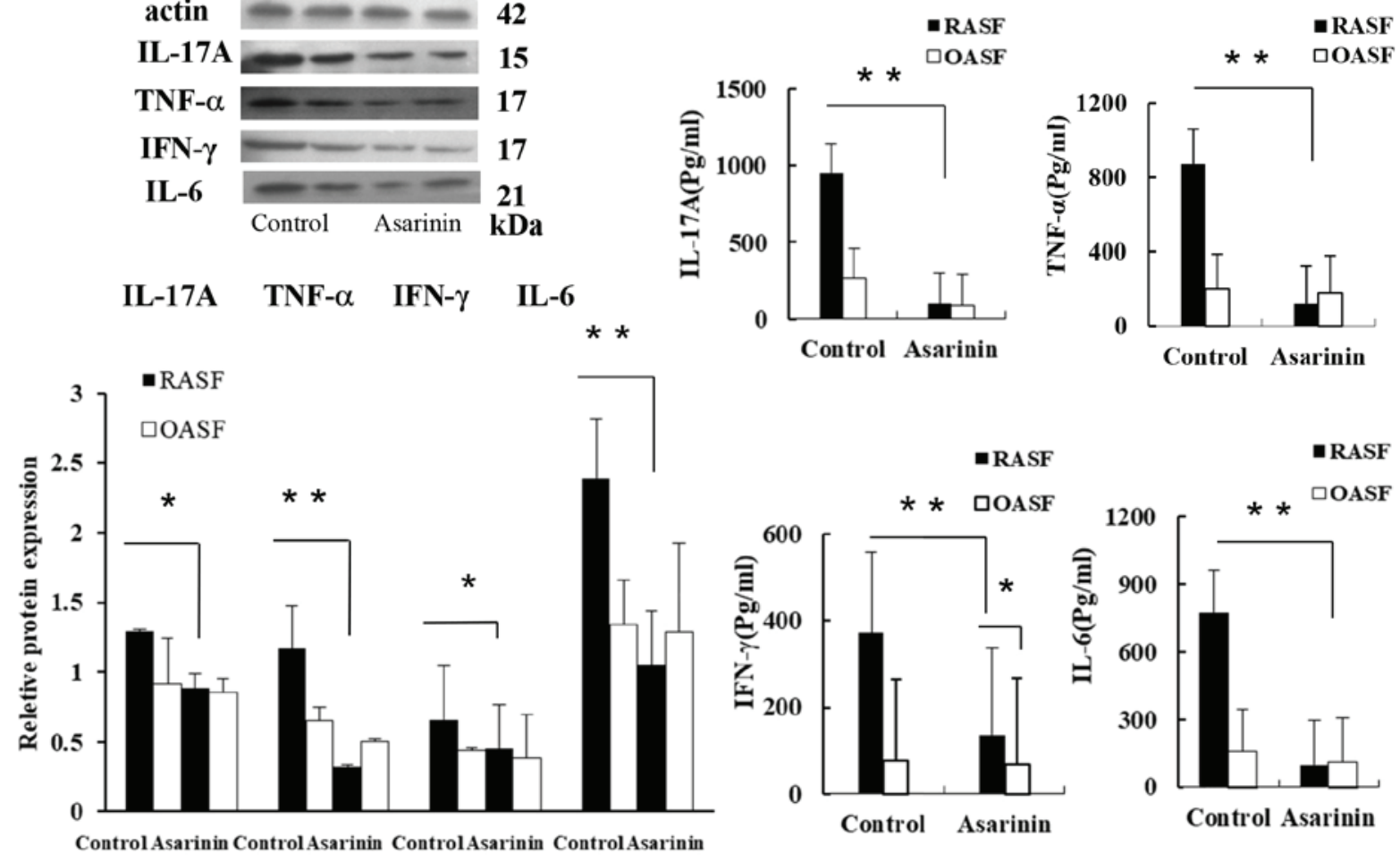

Figure 3. Effect of asarinin on cytokine expression of rheumatoid synoviocytes. (A) Left: Fibroblast-like synovial cell morphology of third generation osteoarthritic synoviocytes. Right: third generation of the fibroblast-like synovial cell morphology of rheumatoid synoviocytes (magnification, $\mathrm{x} 40$ ). (B) Changes in the expression of IL-17A, TNF- $\alpha$, IFN- $\gamma$ and IL- 6 were determined by performing reverse transcription-quantitative PCR. (C) Protein expression of cytokines in rheumatoid synoviocytes. Upper panel: Expression of IL-17A, TNF- $\alpha$, IFN- $\gamma$ and IL- 6 was analyzed using western blotting with $\beta$-actin as a loading control. Lower panel: Density histogram data from three separate western blot analyses (mean \pm standard deviation), which represent the relative expression of IL-17A, TNF- $\alpha$, IFN- $\gamma$ and IL-6. (D) Quantitative analyses of IL-17A, TNF- $\alpha$, IFN- $\gamma$ and IL-6 using ELISA. *P<0.05 and ${ }^{* *} \mathrm{P}<0.01$ vs. control cells. IL, interleukin; TNF, tumor necrosis factor; IFN, interferon; RASF, rheumatoid arthritis synovial fibroblast; OASF, osteoarthritis synovial fibroblast.

different from that of IL-1 and TNF- $\alpha$, which mainly induces the production of immunoglobulins and the formation of acute phase proteins (37-40). Although $\mathrm{T}_{\mathrm{h}} 2$ cells secrete IL-6, IL-6 still serves a role as an inflammatory cytokine. Additionally, $\mathrm{T}_{\mathrm{h}} 17$ cells secrete IL-17, which is generally considered an important inflammatory mediator that modulates local infiltration and tissue injury of inflammatory cells by inducing the expression of other inflammatory cytokines, such as IL-6 and TNF- $\alpha$, and chemokines, such as monocyte chemotactic protein 1 and macrophage inflammatory protein-2 $(1,6)$. Mice deficient in IL-17 exhibit reduced severity of arthritis, and mice with increased IL-17 levels exhibit exacerbated levels of the disease $(41,42)$. Inflammatory cytokines are selectively recruited to the synovial cavity in RA and various relevant cytokines in the synovial tissue were detected in the present study $(13,43)$. IL-1 and TNF- $\alpha$ stimulate the proliferation of FLS to secrete cytokines and prostaglandins, inducing FLS proliferation (44). FLS produce large numbers of cytokines (including IL-1, TNF- $\alpha$ and IL-6) in spontaneous and stimulating conditions (45-47). The cytokine production profiles by synovial cells in patients with RA and OA are similar regarding the types of cytokines produced $(44,48)$. However, the quantity of inflammatory cytokines secreted in patients with RA is significantly higher compared with that in patients with OA, indicating that synovial cells may be excessively activated in patients with RA (49). Streptococcal cell wall induced arthritis 
A

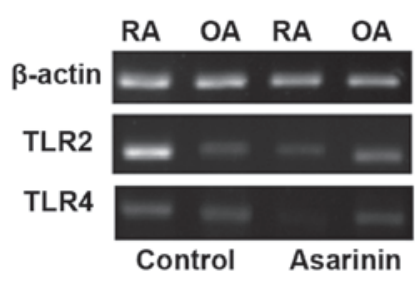

B

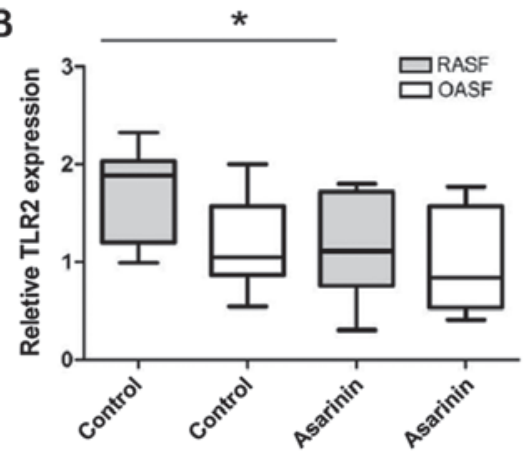

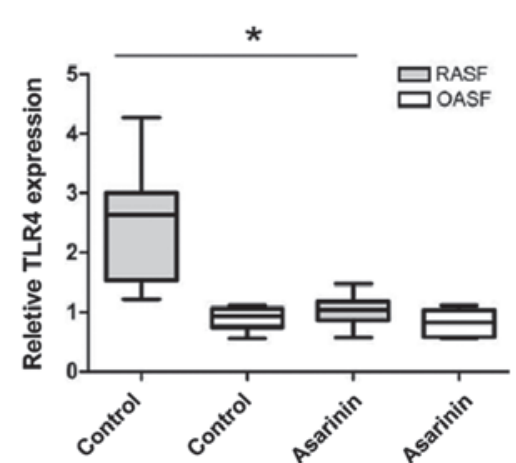

Figure 4. Expression of TLRs in RASFs. (A) The expression of TLR 2 and TLR4 was determined by reverse transcription-quantitative PCR with $\beta$-actin as the loading control. (B) Changes in the expression of TLR 2 and TLR4 were determined by performing reverse transcription-quantitative PCR. $* \mathrm{P}<0.05$ vs. control cells. TLR, Toll-like receptor; SF, synovial fibroblast; RASF, rheumatoid arthritis SF; OASF, osteoarthritis SF.

is markedly reduced in TLR $2^{-/-}$mice and TLR4 deficiency results in impaired osteoclast formation as well as a reduction in Th-17 inducing cytokines such as IL-1, IL-6 and IL-23 in the same animals (50). TLR4 and TLR2 serve crucial roles in the production of inflammatory cytokines and TLR activation exacerbates RASF-mediated inflammatory $T_{h} 1$ and $T_{h} 17$ responses (11). In conclusion, the inhibitory effect of asarinin drug serum on human RASFs may be achieved by inhibiting $T_{h} 1$ and $T_{h} 17$ cytokines via the suppression of TLR 2 and TLR 4 .

\section{Acknowledgements}

Not applicable.

\section{Funding}

The present study was supported by the Fund of Heilongjiang Science and Technical Office (grant no. QC2011C059), the Harbin Science and Technology Bureau of Heilongjiang Province (grant no. 2012RFQXS020), the Postdoctoral Foundation of China and Heilongjiang Province (grant nos. 2013M531081, LBH-Z11004 and LBHQ15138) and the Excellent Innovative Talents Support Program of Heilongjiang University of Traditional Chinese Medicine (Excellent Young Academic Leader; grant no. 2018).

\section{Availability of data and materials}

The datasets used and/or analyzed during the current study are available from the corresponding author on reasonable request.

\section{Authors' contributions}

QD, YL and JL conceived and designed the current study, and wrote and revised the manuscript. QD, MW and YZL conducted the experiments and analyzed and interpreted the data. All authors read and approved the final manuscript.

\section{Ethics approval and consent to participate}

The animal experiments were performed in accordance with the guidelines for the Care and Use of Laboratory Animals and were approved by the Institutional Animal Care and Use
Committee of Harbin Medical University. The study protocols, consent forms and consent procedure were approved by the Institutional Medical Ethics Review Board of the Second Affiliated Hospital of Harbin Medical University.

\section{Patient consent for publication}

Not applicable.

\section{Competing interests}

The authors declare that they have no competing interests.

\section{References}

1. Dai Q, Li Y, Zhang F, Yu H and Wang X: Therapeutic effect of low-dose IL-18 combined with IL-10 on collagen-induced arthritis by down-regulation of inflammatory and Th1 responses and induction of Th2 responses. Rheumatol Int 29: 615-622, 2009.

2. Guggino G, Giardina AR, Raimondo S, Giardina G, Sireci G, Dieli F, Peralta M, Alessandro R, Triolo G and Ciccia F: Targeting IL-6 signalling in early rheumatoid arthritis is followed by Th1 and Th17 suppression and Th2 expansion. Clin Exp Rheumato 132: 77-81, 2014.

3. Gonzalo-Gil E, Criado G, Santiago B, Dotor J, Pablos JL and Galindo M: Transforming growth factor (TGF)- $\beta$ signalling is increased in rheumatoid synovium but TGF- $\beta$ blockade does not modify experimental arthritis. Clin Exp Immunol 174: 245-255, 2013.

4. Thepmalee C, Panya A, Junking M, Chieochansin T and Yenchitsomanus PT: Inhibition of IL-10 and TGF- $\beta$ receptors on dendritic cells enhances activation of effector T-cells to kill cholangiocarcinoma cells. Hum Vaccin Immunother 14: 1423-1431, 2018.

5. Dai Q, Li J, Yun Y and Wang J: Toll-like receptor 4-myeloid differentiation primary response gene 88 pathway is involved in the shikonin treatment of CIA by regulating Treg/Th17 expression. Evid Based Complement Alternat Med 2018: 2428546, 2018.

6. Dai Q, Li Y, Yu H and Wang X: Suppression of Th1 and Th17 responses and induction of Treg responses by IL-18-expressing plasmid gene combined with IL-4 on collagen-induced arthritis. Biomed Res Int 2018: 5164715, 2018.

7. Müller-Ladner U, Ospelt C, Gay S, Distler O and Pap T: Cells of the synovium in rheumatoid arthritis. Synovial fibroblasts. Arthritis Res Ther 9: 223, 2007.

8. Schönfeld C, Pap T, Neumann E and Müller-Ladner U: Fibroblasts as pathogenic cells in rheumatic inflammation. Z Rheumatol 74: 33-38, 2015 (In German).

9. Davis LS, Cush JJ, Schulze-Koops H and Lipsky PE: Rheumatoid synovial CD4+ T cells exhibit a reduced capacity to differentiate into IL-4-producing T-helper-2 effector cells. Arthritis Res 3: 54-64, 2001. 
10. Radstake TR, Roelofs MF, Jenniskens YM, Oppers-Walgreen B, van Riel PL, Barrera P, Joosten LA and van den Berg WB: Expression of toll-like receptors 2 and 4 in rheumatoid synovial tissue and regulation by proinflammatory cytokines interleukin-12 and interleukin-18 via interferon-gamma. Arthritis Rheum 50: 3856-3865, 2004.

11. Hu F, Li Y, Zheng L, Shi L, Liu H, Zhang X, Zhu H, Tang S, Zhu L, Xu L, et al: Toll-like receptors expressed by synovial fibroblasts perpetuate Th1 and Th17 cell responses in rheumatoid arthritis. PLoS One 9: e100266, 2014.

12. Elshabrawy HA, Essani AE, Szekanecz Z, Fox DA and Shahrara S: TLRs, future potential therapeutic targets for RA. Autoimmun Rev 16: 103-113, 2017.

13. Jing Y, Zhang YF, Shang MY, Liu GX, Li YL, Wang X and Cai SQ: Chemical constituents from the roots and rhizomes of asarum heterotropoides var. mandshuricum and the in vitro anti-inflammatory activity. Molecules 22: 125, 2017.

14. Gu J, Zhang L, Wang Z, Chen Y, Zhang G, Zhang D, Wang X, Bai X, Li X and Lili Z: The effect of asarinin on toll-like pathway in rats after cardiac allograft implantation. Transplant Proc 47 545-548, 2015

15. Park HJ,Lee KS,Zhao TT, Lee KE and Lee MK: Effects of asarinin on dopamine biosynthesis and 6-hydroxydopamine-induced cytotoxicity in PC12 cells. Arch Pharm Res 40: 631-639, 2017.

16. Zhang LL, Lu SF, Zhang S, Nie HG, Guan ZZ and Yang BF: Effect of asarinin on the acute heart transplantation rejection and the expression of adhesion molecule. Zhongguo Zhong Yao Za Zhi 31: 494-497, 2006 (In Chinese).

17. Dai Q, Wang M, Li Y and Li J: Amelioration of CIA by Asarinin is associated to a downregulation of TLR9/NF- $\mathrm{KB}$ and regulation of Th1/Th2/Treg expression. Biol Pharm Bull 42: 1172-1178, 2019.

18. Xiong Y, Jing Y, Shang M, Li C, Ye J, Wang X and Cai S: Anti-inflammatory and anti-nociceptive effects in mice of water and ethanol extracts of roots and rhizomes of Asarum heterotropoides var. mandshuricum. Zhongguo Zhong Yao Za Zhi 34: 2252-2257, 2009 (In Chinese)

19. He Q, Liu Q, Chen Y, Meng J and Zou L: Long-zhi decoction medicated serum promotes angiogenesis in human umbilical vein endothelial cells based on autophagy. Evid Based Complement Alternat Med 2018: 6857398, 2018.

20. Hu X, Lu H, Deng YL, Wan Q and Yie SM: Effect of rat medicated serum containing Zuo Gui Wan and/or You Gui Wan on the differentiation of stem cells derived from human first trimester umbilical cord into oocyte-like cells in vitro. Evid Based Complement Alternat Med 2015: 825805, 2015.

21. Aaltonen K, Niemelä T,Sankari S and Tulamo RM: Determination of the unsaturated disaccharides of hyaluronic acid in equine synovial fluid by high-performance liquid chromatography and fluorescence detection. Acta Vet Scand 57: 12, 2015.

22. Di Y, Zhao M, Nie Y, Wang F and Lv J: A high-performance liquid chromatography: Chemiluminescence method for potential determination of vardenafil in dietary supplement. J Autom Methods Manag Chem 2011: 982186, 2011.

23. Aletaha D, Neogi T, Silman AJ, Funovits J, Felson DT, Bingham CO III, Birnbaum NS, Burmester GR, Bykerk VP, Cohen MD, et al: 2010 rheumatoid arthritis classification criteria: An American college of rheumatology/european league against rheumatism collaborative initiative. Arthritis Rheum 62: 2569-2581, 2010.

24. Klein K, Aeschlimann A, Jordan S, Gay R, Gay S and Sprott H: ATP induced brain-derived neurotrophic factor expression and release from osteoarthritis synovial fibroblasts is mediated by purinergic receptor P2X4. PLoS One 7: e36693, 2012.

25. He Y, Zhu Q, Chen M, Huang Q, Wang W, Li Q, Huang Y and Di W: The changing 50\% inhibitory concentration (IC50) of cisplatin: A pilot study on the artifacts of the MTT assay and the precise measurement of density-dependent chemoresistance in ovarian cancer. Oncotarget 25: 70803-70821, 2016.

26. Rai Y, Pathak R, Kumari N, Sah DK, Pandey S, Kalra N, Soni R, Dwarakanath BS and Bhatt AN: Mitochondrial biogenesis and metabolic hyperactivation limits the application of MTT assay in the estimation of radiation induced growth inhibition. Sci Rep 8: 1531, 2018

27. Livak KJ and Schmittgen TD: Analysis of relative gene expression data using real-time quantitative PCR and the 2(-Delta Dleta C(T)) method. Methods 25: 402-408, 2001

28. Neumann E, Lefèvre S, Zimmermann B, Gay $S$ and Müller-Ladner U: Rheumatoid arthritis progression mediated by activated synovial fibroblasts. Trends Mol Med 16: 458-468, 2010.

29. Dai Q, Fang J and Zhang FS: Dual role of shikonin in early and late stages of collagen type II arthritis. Mol Biol Rep 36: 1597-1604, 2009.
30. Kinoshita M, Kuranaga N, Matsumoto A, Ono S, Shinomiya N, Hiraide $\mathrm{H}$ and Seki S: Multiple interleukin-18 injections promote both mouse Th1 and Th2 responses after sublethal Escherichia coli infection. Clin Exp Immunol 143: 41-49, 2006.

31. Weaver CT, Harrington LE, Mangan PR, Gavrieli M and Murphy KM: Th17: An effector CD4 T cell lineage with regulatory T cell ties. Immunity 24: 677-688, 2006.

32. Veenbergen S, Smeets RL, Bennink MB, Arntz OJ, Joosten LA, van den Berg WB and van de Loo FA: The natural soluble form of IL-18 receptor $\beta$ exacerbates collagen-induced arthritis via modulation of T-cell immune responses. Ann Rheum Dis 69: 276-283, 2010.

33. Croft AP, Naylor AJ, Marshall JL, Hardie DL, Zimmermann B, Turner J, Desanti G, Adams H, Yemm AI, Müller-Ladner U, et al: Rheumatoid synovial fibroblasts differentiate into distinct subsets in the presence of cytokines and cartilage. Arthritis Res Ther 18: 270, 2016.

34. Bustamante MF, Garcia-Carbonell R, Whisenant KD and Guma M: Fibroblast-like synoviocyte metabolism in the pathogenesis of rheumatoid arthritis. Arthritis Res Ther 19: 110, 2017.

35. Lefèvre S, Knedla A, Tennie C, Kampmann A, Wunrau C, Dinser R, Korb A, Schnäker EM, Tarner IH, Robbins PD, et al: Synovial fibroblasts spread rheumatoid arthritis to unaffected joints. Nat Med 15: 1414-1420, 2009.

36. Alzabin S, Abraham SM, Taher TE, Palfreeman A, Hull D, McNamee K, Jawad A, Pathan E, Kinderlerer A, Taylor PC, et al: Incomplete response of inflammatory arthritis to TNF- $\alpha$ blockade is associated with the Th17 pathway. Ann Rheum Dis 71: 1741-1748, 2012

37. Bevington SL, Cauchy P, Withers DR, Lane PJ and Cockerill PN: $\mathrm{T}$ cell receptor and cytokine signaling can function at different stages to establish and maintain transcriptional memory and enable T helper cell differentiation. Front Immunol 8: 204, 2017.

38. Macallan DC, Borghans JA and Asquith B: Human T cell memory: A dynamic view. Vaccines (Basel) 4: E5, 2017.

39. Yanes RE, Gustafson CE, Weyand CM and Goronzy JJ: Lymphocyte generation and population homeostasis throughout life. Semin Hemato 54: 33-38, 2017.

40. Nakae S, Nambu A, Sudo K and Iwakura Y: Suppression of immune induction of collagen-induced arthritis in IL-17-deficient mice. J Immunol 171: 6173-6177, 2003.

41. LubbertsE,vanden BersselaarL,Oppers-WalgreenB,SchwarzenbergerP, Coenen-de Roo CJ, Kolls JK, Joosten LA and van den Berg WB: IL-17 promotes bone erosion in murine collagen-induced arthritis through loss of the receptor activator of NF- $\mathrm{BB}$ ligand/osteoprotegerin balance. J Immunol 170: 2655-2662, 2003.

42. Mellado M, Martínez-Muñoz L, Cascio G, Cascio G, Lucas P, Pablos JL and Rodríguez-Frade JM: T cell migration in rheumatoid arthritis. Front Immunol 27: 384, 2015.

43. Millán $\mathrm{O}$ and Brunet M: Cytokine-based immune monitoring. Clin Biochem 49: 338-346, 2016

44. Sun J, Yan P, Chen Y, Chen Y, Yang J, Xu G, Mao H and Qiu Y: MicroRNA-26b inhibits cell proliferation and cytokine secretion in human RASF cells via the Wnt/GSK-3 $\beta / \beta$-catenin pathway. Diagn Pathol 10: 72, 2015.

45. Shikhagaie MM, Germar K, Bal SM, Ros XR and Spits H: Innate lymphoid cells in autoimmunity: Emerging regulators in rheumatic diseases. Nat Rev Rheumatol 13: 164-173, 2017.

46. Ahmad SF, Zoheir KM, Abdel-Hamied HE, Ashour AE, Bakheet SA, Attia SM and Abd-Allah AR: Amelioration of autoimmune arthritis by naringin through modulation of T regulatory cells and Th1/Th2 cytokines. Cell Immunol 287: 112-120, 2014.

47. Lubberts E: Th17 cytokines and arthritis. Semin Immunopathol 32: 43-53, 2010.

48. de Lange-Brokaar BJ,Ioan-Facsinay A, van Osch GJ,Zuurmond AM, Schoones J, Toes RE, Huizinga TW and Kloppenburg M: Synovial inflammation, immune cells and their cytokines in osteoarthritis: A review. Osteoarthritis Cartilage 20: 1484-1499, 2012.

49. Firestein GS: Invasive fibroblast-like synoviocytes in rheumatoid arthritis. Arthritis Rheum 39: 1781-1790, 1996.

50. Abdollahi-Roodsaz S, Joosten LA, Helsen MM, Walgreen B, van Lent PL, van den Bersselaar LA, Koenders MI and van den Berg WB: Shift from toll-like receptor 2 (TLR-2) toward TLR-4 dependency in the erosive stage of chronic streptococcal cell wall arthritis coincident with TLR-4-mediated interleukin-17 production. Arthritis Rheum 58: 3753-3764, 2008.

This work is licensed under a Creative Commons Attribution-NonCommercial-NoDerivatives 4.0 International (CC BY-NC-ND 4.0) License. 